\title{
Digital marketing on destination sustainability Study case: Romanian Ecotourism
}

\author{
Alexandru Valentin TEODOROV \\ Bucharest University of Economic Studies, Bucharest, Romania \\ alexandruvalentin.teodorov@stud.ase.ro \\ Manuela Liliana MURESAN \\ Bucharest University of Economic Studies, Bucharest, Romania \\ manumuresan@gmail.com \\ Diana Mariana DINU \\ Bucharest University of Economic Studies, Bucharest, Romania \\ dianamariana.dinu@gmail.com \\ Alexandra Cristina DINU \\ Bucharest University of Economic Studies, Bucharest, Romania \\ alexandractistina.dinu@mk.ase.ro
}

\begin{abstract}
Marketing and publicity have played a very significant role in promoting touristic destinations. Over the years, destinations promoted in papers, magazines and even movies, have become more and more crowded. This phenomenon even happened to the extent that it threatens the local environment and the wellbeing of locals. By studying recent news regarding popular tourist destinations, the article will observe the shift in the mindset of both tourists and policy makers. Therefore, should campaigns be held to raise awareness regarding different threats a destination faces, a shift of mindset will occur. This can be observed from the point of view of policy makers, locals and even tourists. The aim of this article is to study and compare both, publicity done for sustainability and publicity done for the sake of popularizing a touristic destination. Through this comparison the article wants to see if there are any changes in the behavior of tourists when reaching specifically advertised destinations but also if certain types of publicity have determined policy makers to take a stand for sustainability.
\end{abstract}

Keywords: sustainability, marketing, publicity, policy, tourism, destination management organization (DMO).

\section{Introduction}

If we analyze the effect of marketing on the destination, we cannot make a review of the management of the tourist destination, without talking about the role of the destination management organization (DMO) in promoting the tourist destination. The definitions identified over the time of the tourist destination were different, but to a large extent the destination it is associated with the geographical space or with a locality / area / region / country where tourists stay at least one night. (Chaşovschi et all., 2016).

The destination includes tourist products, support services, attractions and tourist resources (WTO, 2007). "The destinations are a mixture of tourist products, which offers an integrated experience for consumers." (Buhalis, 2000) "The destination is a set of products, services, natural and artificial tourist attractions, capable of attracting tourists to a certain place." (Leiper et al., 1995) 
For example in Romania we identify a legal framework for the destination management organization, LAW no. 275 of November 23, 2018 regarding the approval of the Government Ordinance no. 15/2017 for amending and supplementing Government Ordinance no. 58/1998 regarding the organization and conduct of tourism activity in Romania: "destination management organization - legal entity, which carries out the tourism development policy of the destination, including the marketing policy of the destination, in accordance with the legal provisions in force;" Thus, we keep in mind that the DMO is an entity with legal personality, which works by associating the representatives of the local public authorities from the destination, with representatives from the private environment and, as the case may be, with representatives of other relevant entities (promotion associations, professional associations, NGOs, administrators of protected natural areas and others), based on a partnership, which ensures the implementation of the marketing policy and the coordinated management of the components of the destination in order to develop and capitalize on the tourist potential of the destination; This is the aim of the coalition of organizations and stakeholders for the development and exploitation of the tourist potential of the destination.

The contemporary opinion, generally supported by economically developed countries that are in the top 10 tourist destinations globally, tends to underline the broader functional vision, that the DMO was only a marketing entity. This contemporary view suggests that a DMO should be concerned with tourism development in its broadest sense - involving product development, community development, experience development, promotions, sales and marketing, as well as territorial development, appearance and destination presentation - it itself as encountered by the tourist.

It is very important to understand the tourist needs when we think about the marketing of a preferred destination for the consumer. For this, we need current market information from a market research and, of course, from the analysis of consumer segmentation. This principle in the field of marketing can be easily used within the DMO. We know that the tourism marketing domain is a very cluttered and noisy space, at both the national and international level. It is exceptionally difficult for a small tourism entity - for example a small municipality - to cut through this noise and make itself heard. In tourism marketing terminology, failure to achieve "cut through" is a well-recognized challenge. (Kotler, 2002)

\section{Literature review}

\section{The role of DMO's in promoting sustainability at the touristic destination}

The DMO plays an essential role in the objective analysis of the activity of the local tourism industry in the matter of promotion and the expectations of the targeted markets. The DMO must also ensure the reality of the information transmitted through promotion and intervene as soon as it finds that disappointment may occur on a market segment due to wrong actions. Very important to remember is that the promotion is effective only if the other marketing mix elements (price, product, distribution) are being used correctly. Thus, the public sector and public sector managers have an equally important role in shaping the visitor experience. While the private sector creates and delivers services and experiences for visitors, many do so in spaces that they do not own.

A good example for the impact of marketing on destination sustainability is that the DMO supporting Gothenburg as a destination, is not only active in developing and maintaining a very high standard in sustainable tourism, but that it uses this achievement (a high-performing sustainable destination) as a source of economic competitive advantage and places this message 
at the center of its promotion and marketing programs so as to stand out in international markets. So "sustainability" performs not only as an end in itself but also as a tool to provide the destination with an enhanced level of competitive advantage. (Göteborg \& Co, 2019)

The central advantage regarding the functioning and focus of a DMO is that, in recent years, it has moved from the idea of a DMO representing a single marketing and promotion engine for the area concerned. In addition to marketing and promotion, a destination management organization will be concerned with the functions of the offer, such as product innovation, product development, product investment, product presentation, experience development, animation, communications technology, storytelling, sustainability, training and education, digitalization development and human resource management. (UNWTO, 2007)

If we refer to the case of Romania, the strategic objective and the concentration of the DMO activities in relation to the services for visitors are not unique, therefore the DMOs should focus on improving the quality of the visitors destination experience in order to increase the accommodation duration and to maximize the visitors' expenses and return to the holiday destination.

From the perspective of public policymakers, all efforts of decision-makers should be directed to facilitate potential visitors to plan and book their visits to/within the destination and to navigate around it, to ensure the highest quality of good, personal income and providing information from key visitors and to be proactive in supporting DMO branding, by providing directly relevant information and by facilitating the storytelling of interest to visitors.

\section{Sustainability development within the touristic destination}

When speaking about sustainability in tourism, there is a whole array of factors that one must take into account. While there is no unified definition of this term, it is of utmost importance to take into account what is it, that one implies when using this term in relation to touristic destination. According to (Dangi et Jamal, 2016), there are three main pillars support tourism sustainability: social, economic and environmental. According to the World Tourism Organization (2012) sustainable tourism "takes full account of its current and future economic, social and environmental impacts, addressing the needs of visitors, the industry, the environment, and host communities". As can be observed, the same key elements can be found in both definitions. However, with the growing importance of heritage, the aspect of culture cannot be left out of the enquiry. As can be seen in Figure 1, there is a close link between all the dimensions (economic, socio-cultural and environmental) but if one is left out of the equation, sustainable development cannot be fully achieved. 


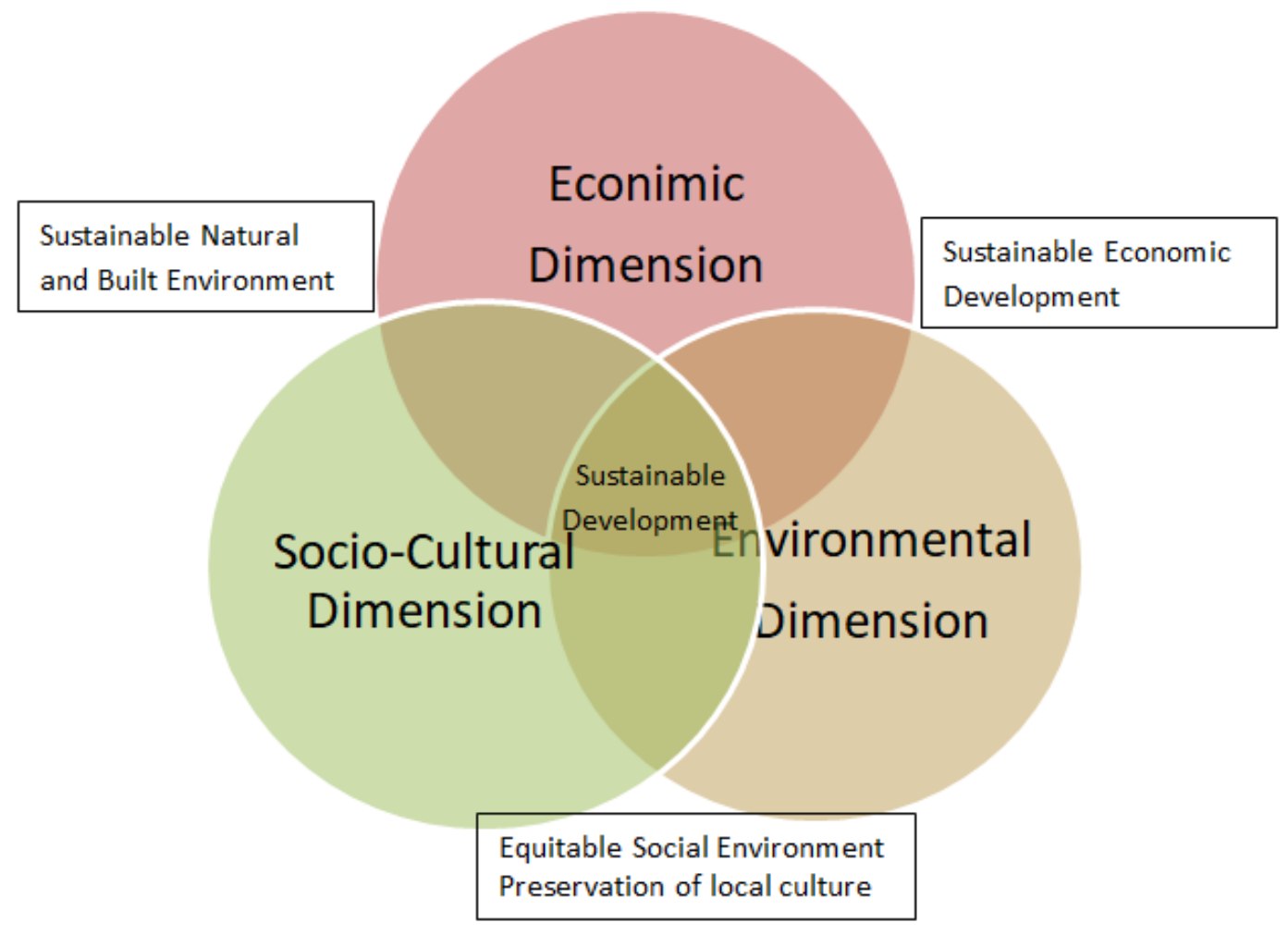

PICBE | 862

Figure 1. Sustainable development

Source: Adapted from Raath and Hay (2018)

As a market segment, ecotourism does not encompass tourism as a whole, as it is in direct correlation with three main branches of tourism: cultural, rural and nature - as can be observed in Figure 2. However, this does not diminish its importance in the touristic market. People are becoming more willing to travel to sustainable destinations. What is more the number of tourists traveling in a sustainable manner has risen steadily with about 5\% every year (O'Connor, 2018) and with the ongoing promotion of ecotourism this trend is ensured a continuous rise.

In order to incentivize the growth of sustainability among business in the hospitality sector, special labels were given to accommodation sites should they fulfil certain criteria. Such examples are the EU Ecolabel and the EMAS (European Commission, 2016a). While the first one rewards behaviors complementary to the pillars mentioned in Figure 1 such as preserving natural habitat; maintaining cultural resources; promoting wellbeing for the community as a whole; limiting tourism impact on the environment and so on; the second one reward management practices from supply chain, construction and transport, to the moment that the tourist reaches the destination.

To support sustainability, the EU also created a monitoring system called "European Tourism Indicators System" (ETIS) in order to in order to better ecological practices. (European Commission, 2016b). 


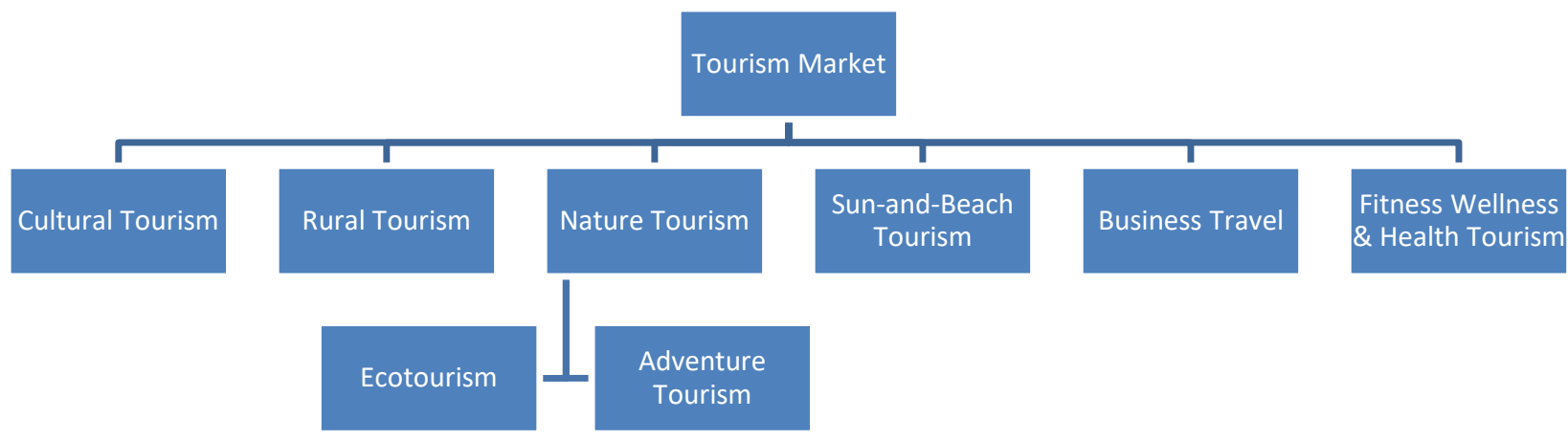

PICBE $\mid 863$

Figure 2. Ecotourism as market segment

Megan Epler Wood, Ecotourism: Principles, Practices and Polices for Sustainability (2002) cited in Strategia naţională de dezvoltare a ecoturismului în România - context, viziune și obiective - 2016-2020

In the case of Romania, a steady growth in ecotourism accommodation has been observed ever since 2005. One study made by Gheorghe (2015), shows the registry of 2013 to have a steady growth of $17.41 \%$ per year for touristic guesthouses and $6.63 \%$ growth for rural guesthouses. The latest data from the Insse.ro (2020a) do not reveal a surprising increase in number of accommodations. However, once the index of net use of tourist accommodation capacity is taken into account, one can observe that the tourist pensions registered a growth of $22.4 \%$ while agritourism registered a growth of $20.4 \%$ from 2018 (Insse.ro, 2020b).

\section{Methodology}

The current article focuses on the analysis of DMO's and their means to promote sustainability within the touristic destination. In order to do so, the main elements that were taken into consideration were the online presence of the DMO and the way in which it presents different destinations. As was mentioned in the article, the UNWTO tries to attract people towards sustainable tourism. If such is the case, the current study aims to observe the online presence of the AER DMO and observe the strength if its online presence. For this, multiple online channels have been observed in order to conclude on their impact on the consumer as well as their overall strengths and weaknesses, that are vital to know in order to create a better strategy.

The digital channels Romanian DMO, AER is using to promote Romanian ecotourism An example of destination management organization (DMO) in Romania represents AER, which gathers 56 ecotourism suppliers, from 11 Romanian eco-touristic destinations. As a DMO, AER has a vital role in developing a marketing strategy, in order to increase the awareness of the destinations via all the marketing channels.

An effective marketing strategy is translated through the number of individuals following and consuming the digital content and finally purchasing a vacation package. But ultimately the greatest indicator of effectiveness is the level of engagement and loyalty that the customer pays back, by returning for more experiences, thus more purchases. 
We have exposed below the digital channels and AER is promoting the Romanian ecotouristic destinations. In the conclusions and recommendations, we depict the untouched areas that AER can add to its digital marketing strategy that contribute to the visibility and awareness and also to customer loyalty and engagement.

- Website - AER is managing the eco-romania.ro website

PICBE | 864

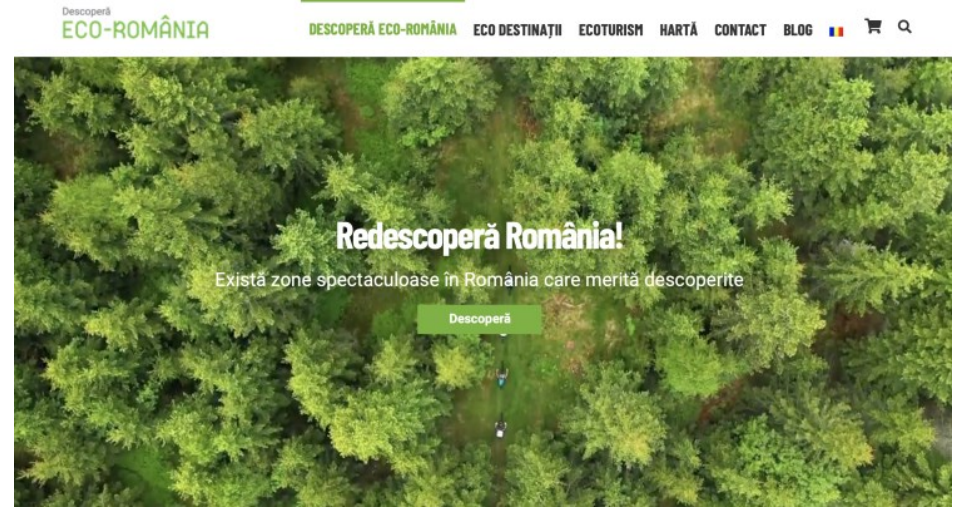

Figure 3. Home Page Descopera Eco-Romania

- Blog - 17 blogposts
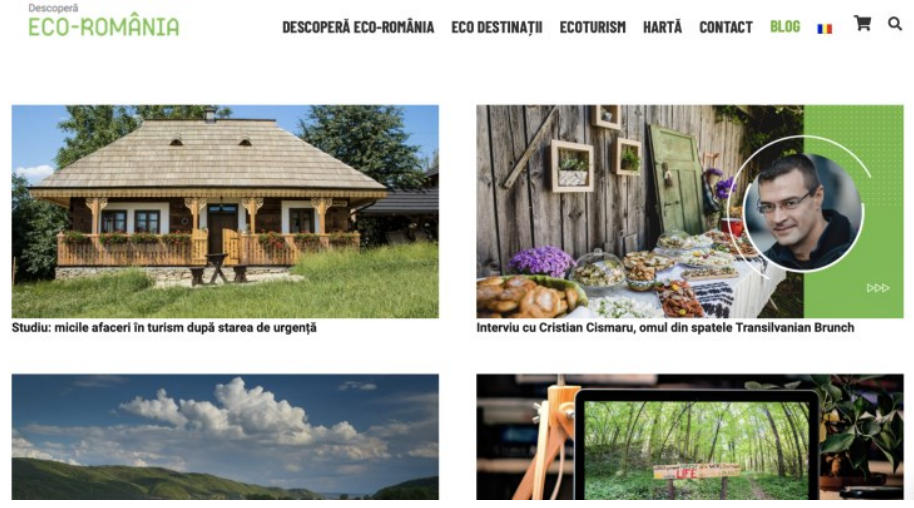

Figure 4. Blog Posts Descopera Eco-Romania

- Social Media - the Facebook account has approximately 9 thousand followers

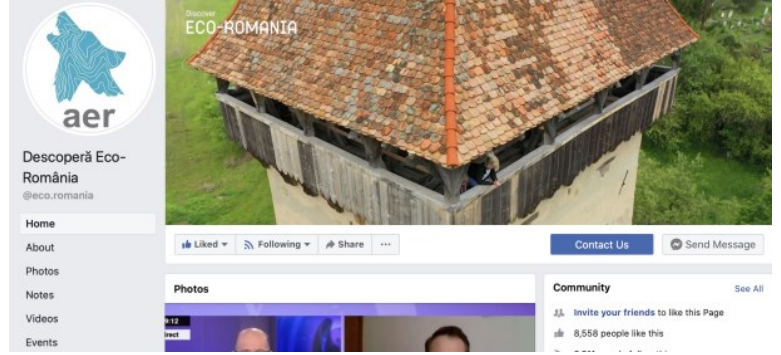

Figure 5. Descopera Eco-Romania Facebook Page

- YouTube channel - created almost half a year ago, with 16 videos uploaded and with an average of 4,000 video visualizations 


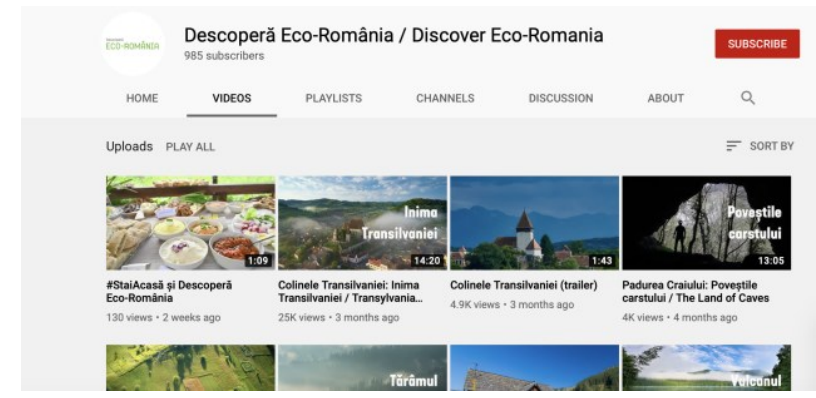

Figure 6. Descopera Eco-Romania - Youtube Channel

PICBE | 865

Source: youtube.com

\section{Results and discussions}

The efforts of AER to promote the Romanian ecotourism are commendable, especially the upon quality of the content they deliver. They understood that a good promotion of touristic services stands behind emotions, which are usually generated visually. The videos, digital catalogues and social media posts are well documented with outstanding and high-quality images, that trigger the desire to visit the promoted destinations.

However, there are uncovered areas that have a significant potential in generation more awareness, engagement and help members gain loyal customers:

\section{Customers and partners database.}

A CRM system with a healthy database is the key element in building a suitable marketing strategy. Indeed, implementation of a CRM system requires high financial and time investment

\section{E-mail marketing.}

Once implemented a CRM system, email marketing campaigns are a natural step further. Nurturing the customer with the latest news about the destinations, or events.

\section{Online loyalty program.}

Such an initiative is suitable for engaging customers and having them choose again Romanian eco-touristic destination as their next experience. Incentives such as discounts on the next trip, free activities like horse riding, photography albums with the places they have visited or member cards to gain points to pay the museum entrance fee, can be part of a loyalty strategy.

\section{Online community.}

Linking members with their customers via an online community would create the feeling of familiarity, which will trigger a higher level of engagement. In addition, new customers would be more confident when purchasing the members services, relying on other customers reviews and recommendations. Also, a section for the members to share best practices or even to create partnerships would contribute to building stronger collaborative relationship.

\section{Conclusion}

One of the main solutions for the digitalization of tourism refers to its promotion in the online environment. This aspect as was observed in the article be achieved through several variants, including the optimization of web pages specific to points of interest, which become especially Mobile Friendly, because the vast majority of accesses are made with the help of smart devices. 
The optimization of the web pages will be done in several stages, the most important being the updating of the information about the tourist points, the uploading of some recent pictures and the assurance of a fast loading of the sites.

Social media platforms continue to be the main marketing element of our generation, offering the opportunity to communicate with customers and potential tourists, offering the opportunity to build new relationships with them and strengthen relationships with existing ones. Social networks allow the wide promotion of various travel offers, for example holiday promotions, early booking, etc., or special events, such as tourism fairs. These platforms allow users to provide reviews on the areas visited or the services used in these areas, but also to post content created by them to attract the attention of others. The AER case that was observed has a good social media presence on one such platform, but should consider extending in order to follow current trends.

Overall, one could observe the efforts of AER to promote the Romanian ecotourism. Fortunately, such efforts do not go unrewarded as ecotourism is on a continuous rise.

\section{Acknowledgement}

"This paper was co-financed by The Bucharest University of Economic Studies during the PhD Program"

\section{References}

Buhalis, D. (2000). Marketing the competitive destination of the future, in Tourism Management, No. 21;

Chaşovschi, C., Bähre, H., Hildebrandt, W., Maurin, M. (2016) - Centrul de informare turistică: ghid practic, Ed. a 3-a, rev. - Bucureşti, Editura Didactică şi Pedagogică;

Dangi, T., Jamal, T., 2016. An Integrated Approach to "Sustainable Community-Based Tourism". Sustainability. 8, 475;

European Commission. (2016). Sustainable tourism. [online] Available at: https://ec.europa.eu/growth/sectors/tourism/offer/sustainable_en [Accessed 10 February 2020].

European Commission. (2016). European Tourism Indicators System for sustainable destination management. [online] Available at: https://ec.europa.eu/growth/sectors/tourism/offer/sustainable/indicators_en [Accessed 15 February 2020].

Gheorghe, A. (2015). Macro Analysis of the Romanian Ecotourism. [online] Available at: http://www.revistadestatistica.ro/supliment/wp-content/uploads/2015/07/RRSS_6_2015_A05.pdf [Accessed 11 April 2020].

Insse.ro. (2020a). capacitatea de cazare turistica existenta $\mid$ Institutul Național de Statistică. [online] Available at: https://insse.ro/cms/ro/tags/capacitatea-de-cazare-turistica-existenta [Accessed 19 April 2020].

Insse.ro. (2020b). Frecventarea structurilor de primire turistica cu functiuni de cazare | Institutul Național de Statistică. [online] Available at: https://insse.ro/cms/ro/tags/frecventareastructurilor-de-primire-turistica-cu-functiuni-de-cazare-0 [Accessed 5 April 2020].

Kotler, P. (2002). Principles of marketing, 3rd Ed., New York: Prentice Hall; LAW no. 275 of November 23, 2018 regarding the approval of the Government Ordinance no. 15/2017 for amending and supplementing Government Ordinance no. 58/1998 regarding the 
organization and conduct of tourism activity in Romania, ISSUER, PARLIAMENT OF ROMANIA, Published in OFFICIAL MONITOR no. 1027 of December 3, 2018;

Leipner et. al. (1995). Tourism Management. Melbourne: RMIT Press;

Mason, P. (2016) Tourism impacts, planning and management, (3rd edition) Routledge Taylor\&Francis Group, London\&New York,

Nistoreanu, P. (2003) Ecoturism şi turism rural, Editura ASE, Bucureşti;

PICBE | 867

O'Connor L. (2018). Climate Change and the rise of Ecotourism - UN CC:Learn - Medium. [online] Medium. Available at: https://medium.com/@uncclearn/climate-change-and-the-rise-ofecotourism-3d78b9b15c26 [Accessed 30 January 2020].

Raath, S., \& Hay, A. (2018). Preservice Geography Students' Exposure to Systems Thinking and Cooperative Learning in Environmental Education. Journal of Geography, 1-11.

Strasdas, W. (2001) Ökotourismus in der Praxis. Studiekreis für Tourismus und Entwicklung, Ammerland, Germany.

Strasdas, W. (2002) The Ecotourism Training Manual for Protected Area Managers. German Foundation for International Development, Zschotau, Germany.

The Swedish Agency for Economic and Regional Growth (2019)

Wood M. E. (2002), Ecotourism: Principles, Practices and Polices for Sustainability, UNDP;

WTO - World Tourism Organisation. (2007). A Practical Guide to Destination Management. Madrid. 